\title{
PERANAN PETIRTAAN JOLOTUNDO UNTUK MENINGKATKAN KESADARAN SEJARAH PESERTA DIDIK DALAM PEMBELAJARAN SEJARAH
}

\author{
Mirza Nurhalizza ${ }^{1}$, Rully Putri Nirmala Puji², Bambang Soepeno ${ }^{3}$ \\ ${ }^{1,2,3}$ Progam Studi Pendidikan Sejarah Fakultas Keguruan dan Ilmu Pendidikan Universitas Jember \\ Jl. Kalimantan No.37 Jember \\ Alamat e-mail: ${ }^{1}$ mirzanurhalizza07@gmail.com
}

\begin{abstract}
Abstrak
Petirtaan Jolotundo merupakan salah satu peninggalan yang bersejarah dari Kabupaten Mojokerto, Petirtaan ini berupa bangunan candi sehingga sering disebut Petirtaan Candi Jolotundo. Pembelajaran sejarah membutuhkan inovasi seiring perkembangan zaman, diperlukan pengembangan media pembelajaran sehingga ada visualisasi guna mengoptimalisasikan pembelajaran yang ada di kelas. Media pembelajaran audiovisual menjadi salah satu alternative yang dapat digunakan dalam pembelajaran sejarah, media audiovisual menyajikan audio (suara) dan visual (gambar). Tujuan diadakannya penelitian ini yaitu untuk mengetahui keterkaitan penggunaan media audiovisual terhadap kesadaran sejarah peserta didik dalam pembelajaran sejarah, untuk mengetahui keefektivitasan penggunaan media audiovisual terhadap kesadaran sejarah peserta didik di dalam pembelajaran dan untuk mengetahui adanya pengaruh dari penggunaan candi sebagai media audio visual terhadap kesadaran sejarah peserta didik dalam pembelajaran sejarah. Jenis penelitian yang dilakukan dengan menggunakan penelitian kuantitatif dan eksperimen. Teknik pengumpulan data yang digunakan adalah wawancara, observasi dan dokumen. Hasil dari penelitian ini dapat diketahui bahwa pemanfaatan video sebagai media pembelajaran audiovisual dapat meningkatkan kesadaran sejarah bagi peserta didik.
\end{abstract}

Kata Kunci: Petirtaan Jolotundo; media audiovisual; kesadaran sejarah;

\begin{abstract}
Petirtaan Jolotundo is also one of the historical relics of Mojokerto Regency, this temple is a petirtaan so it is often called Petirtaan Jolotundo Temple. In history learning, it is necessary to develop learning media, because in history learning also requires visualization to optimize learning in the classroom. Audiovisual learning media is one alternative that can be used in historical learning, audiovisual media presents audio (sound) and visual (images). The purpose of this research is to find out the relevance of the use of audiovisual media to the historical awareness of students in history learning, to determine the effectiveness of the use of audiovisual media on the historical awareness of students in learning and to determine the influence of the use of the temple as an audio-visual media on participants' historical awareness students in history learning. This type of research is conducted using quantitative research and experiments. Data collection techniques used are interviews, observations and documents. The results of this study can be seen that the use of video as an audiovisual learning media can increase historical awareness for students.
\end{abstract}

Keywords: Petirtaan Jolotundo; audiovisual media; historical awareness;

\section{PENDAHULUAN}

Media pembelajaran merupakan alat bantu yang dipergunakan oleh pendidik dalam memudahkan proses pembelajaran yang ada di dalam kelas, selain itu media 
pembelajaran juga sebagai sebagai salah satu elemen yang sangat penting dalam mengefektivitaskan pembelajaran, tak heran jika media pembelajaran selalu dapat diinovasi dan dikembangkan dalam rangka pemenuhan kebutuhan pendidik untuk mengefektivitaskan pembelajaran melalui sebuah media. Media pembelajaran juga dipergunakan sebagai alat komunikasi antara pendidik terhadap peserta didiknya, sehingga dengan adanya sebuah media dapat menjadikan sebuah solusi bagi peserta didik untuk mampu memahami serta menerima informasi yang diberikan oleh pendidik. Media yang dimandaatkan sebagai alat bantu pendidik dalam memberikan informasi ke peserta didik ini terdiri dari berbagai macam misalnya slide, gambar, foto, video, grafik dan lain-lain.

Pembelajaran sejarah sejatinya merupakan sarana yang strategis untuk menanamkan nilai-nilai luhur dan warisan bangsa Indonesia kepada generasi penerus bangsa, yang dimaksud dalam hal ini adalah peserta didik.Atau dapat dikatakan bahwa melalui pembelajaran sejarah dapat menumbuhkan dan membangun mental bagi peserta didik sebagai generasi penerus bangsa. Adanya pembelajaran sejarah diharapkan dapat berimbas positif bagi peserta didik, terutama dalam kaitanya dengan tumbuhnya kesadaran sejarah bagi generasi muda. Adanya pendidikan sejarah bertujuan untuk: (a) membangun kesadaran peserta didik akan pentingnya waktu dan tempat yang mana merupakan suatu proses dari masa kini, masa lampau dan masa yang kana datang. (b) melatih daya kritis peserta didik agar memahami fakta secara benar tentunya dengan didasarkan pada pendekatan ilmiah dan metodologinya, (c) menumbhkan apresiasi dan pengahrgaan kepada peserta didik terhadap peninggalan bersejarah Indonesia, (d) menumbuhkan pemahaman peserta didk terhadap sejarah panjang bangsa Indonesia, (e) menumnuhkan kesadaran pada peserta didik sebagai bagian dari bangsa Indonesia (Aman, 2011)

Pembelajaran sejarah memegang peranan penting untuk memunculkan kesadaran sejarah bagi peserta didik. Isi dari pembelajaran sejarah bukan hanya melulu mengenai menghafal peristiwa ataupun nama tokoh akan tetapi dengan mempelajari sejarah kita dapat memetik hikmah yang telah terjadi di masa lampau dan mengambil hal positif untuk diterapkan dalam kehidupan masa kini dan masa yang akan datang. Pembelajara sejarah tidak selamanya membosankan dan hanya 
terpaku pada buku yang tebal, banyak inovasi yang dapat dilakukan oleh seorang pendidik untuk mengatasi permasalahan tersebut.Seiring dengan majunya perkembangan teknologi yang terus mengalami kemajuan tidak mengherankan teknologi dalam pendidikan pun ikut berkembang dengan pesat, sehingga pendidik harus mampu menyesuaikan dengan perkembangan zaman dan kebutuhan peserta didik didalam pembelajaran sejarah.

Salah satu hasil perkembangan teknologi dalam ranah pendidikan yaitu media pembelajaran. Media pembelajaran merupakan alat bantu yang dipergunakan untuk memudahkan pendidik dalam menyampaikan informasi kepada peserta didik dengan kemasan yang lebih praktis dan tidak monoton. Seiring berkembangnya teknologi informasi dan komunikasi didalam dunia pendidikan bukan hanya sebagai salah satu mata pelajaran saja akan tetapi telah melebr dalam semua mata pelajaran yaitu dengan memanfaatkannya pada proses pembelajaran. Pembelajaran sejarah juga dapat memanfaatkan teknologi informasi sebagai sarana untuk menarik minat belajar peserta didik dan proses pembelajaran lebih kontekstual. Teknologi informasi yang dapat digunakan dapat berupa informasi dari internet, film documenter, video mengenai sejarah, foto-foto sejarah, perpustakaan digital, museum digital dan lain-lain (Sintya, 2018). Media pembelajaran merupakan alat perantara yang dapat dipergunakan untuk menyampaikan sebuah informasi atau pesan pada kegiatan pembelajaran.Media pembelajaran terdiri dari beberapa jenis, sehingga penggunaanya disesuaikan dengan kebutuhan peserta didik. Pembelajaran sejarah didalam proses pembelajarannya bukan hanya terpaku pada metode ceramah saja, kebanyakan pendidik saat kegiatan proses belajar mengajar lebih dominan untuk bercerita. Pembelajaran sejarah cenderung kurang diminati oleh peserta didik karena citra yang membosankan dan materi yang sangat kompleks(Sayono, 2013). Melalui media pembelajaran pendidik dapat memberi esan lebih mendalam kepada peserta didik baik melalui visual, audio maupun audiovisual.

Pembelajaran sejarah pastinya sangat memerlukan bantuan dari media dalam menggambarkan peristiwa yang telah terjadi dimasa lampau dengan rentangan waktu yang cukup lama. Sehingga media pembelajaran yang dapat 
digunakan dalam pembelajaran sejarah sangat beragam, akan tetapi tidak semua media pembelajaran yang dipakai oleh pendidik ini sesuai dengan keinginan peserta didik dalam proses penerimaan informasi yang telah disampaikan oleh pendidik. Biasanya pendidik menggunkaan media pembelajaran yang relative kuno dalam pembelajaran sejarah misalnya hanya mengandalkan buku teks, hanya bercerita tanpa ada gambaran asli mengenai hal yang dijelaskan sehingga peserta didik sulit dalam menginterpretasikan. Sehingga dibutuhkan inovasi dalam penggunaan media pembelajaran yang membantu pendidik dalam mengoptimalkan pengajaran dan penyampaian informasi secara valid kepada peserta didik. Salah satu media yang dapat digunakan yaitu media pembelajaran audiovisual.Media audiovisual ini merupakan kombinasi dari media visual dan video sehingga media ini merupakan pencampuran dari dua jenis media yang mana sering disebut dengan media pandang-dengar.Media audiovisual dalam penelitian ini yakni audiovisual gerak yang mana dapat menampilkan unsur suara dan gambar yang bergerak sepeerti video.

Permasalahan yang terdapat dalam pembelajaran salah satunya bersumber dari ketepatan pemilihan media pembelajaran dalam melaksaknakan kegiatan belajar-mengajar dikelas. Media pembelajaran merupakan elemen yang penting dalam keberhasilan pembelajaran yang ditelah dilakukan tidak jarang karena pemilihan media yang salah sehingga berakibat fatal. Setelah dilakukan observasi yang dilakukan di SMAN 1 Pacet menunjukan bahwa penggunaan media pembelajaran belum sepenuhnya maksimal, pengajar hanya mempergunakan slide dalam pembelajaran bahkan cenderung hanya bercerita sepanajang pembelajaran dikelas, hal ini menjadi hambatan tersendiri dalam keberhasilan pembelajaran serta pemahaman peserta didik mengenai apa yang dijelaskan oleh pendidik. Selain pemilihan media pembelajaran yang cenderung monoton, tidak semua peserta didik dapat menangkap informasi ketika hanya disediakan media pembelajaran visual seperti slide ataupun gambar. Kendala lain yang dialami dalam pembelajaran yakni tidak adanya kesempatan dan waktu untuk pendidik dan juga peserta didik untuk melihat secara langsung benda ataupun peristiwa yang dijelaskan secara lisan oleh pendidik misalnya saja pada penjelasan peninggalan-peninggalan kerajaan 
majapahit, pastinya peserta didik btuh mengvisualisasikan apa yang telah didapatkan selama pembelajaran ke menuju ke gambaran aslinya dengan kata lain mengunjungi situs peninggalan majapahit, akan tetapi tidak tersedianya waktu untuk memvisualisasikanya sehingga media pembelajaran audiovisual ini akan membantu peserta didik dalam menginterpretasikan apa yang telah dipelajar.

Permasalahan yang lain muncul dalam pembelajaran sejarah memang identic dengan kendala pada motivasi peserta didik serta minat untuk mengikuti pembelajaran sejarah karena materi yang banyak, buku yang tebal dan kecenderungan pendidik menggunakan metode ceramah dalam kegiatan belajar mengajar. Selama proses pembelajaran sejarah yaitu kondisi peserta didik yang acuh ketika guru berusaha menyampaikan informasi, kurang tertariknya peserta didik dengan materi yang diajarkan oleh pendidik, serta kurangnya pemanfaatan teknologi untuk mengemas pembelajaran sejarah yang lebih inovatif padahal sarana dan prasarana yang ada disekolah cukup menunjang. Akan tetapi guru hanya menyampaikan informasi atau materi ajar hanya melalui lisan atau buku saja. Hal inilah yang menyebabkanpeserta didik merasa bosan dan terkadang tidak memahami apa yang dijelaskan oleh pendidik.

Candi Jolotundo merupakan salah satu peninggalan bersejarah yang tepatnya berada di Desa Seloliman, Kecamatan Trawas, Kabupaten Mojokerto, Jawa Timur. Candi ini berada di kawasan pegunangan dan uniknya situs ini diapit oleh dua gunung yaitu Gunung Penanggungan dan Welirang(Sulistyo, Widodo, \& A, 2010). Candi ini secara geografis terletak di lereng gunung penanggungan yang letaknya memotong atau melintang sebagian lereng barat gunung.Candi ini sering disebut petirtaan karena memang situs ini memiliki mata air disetiap sudutnya.Candi ini berbentuk persegi yang berukuran 16x13 meter pesegi.Disudut timur dan tenggaranya terdapat kolam kecil yang diatasnya terdapat bangunan candi yang semakin ke atas semakin meruncing.Petirtaan ini dianggap suci bagi penganut Hindu-Siwa.

Peninggalan bersejarah seperti Candi Jolotundo ini pastinya memilki nilai historis yang sangat tinggi dan dibalik bangunan yang berdiri pasti mempunyai nilai dan makna tertentu.Objek ini dipergunakan sebagai objek wisata yang menawarkan 
keindahan candi serta mata air yang dipercaya mujarab dan suci.Selain digunakan sebagai tempat untuk berekreasi, Candi Jolotund juga dipergunakan sebagai wisata religi takkala banyak umat Hindu datang untuk bersembahyang atau untuk bertapa ditempat ini.Di dunia pendidikan candi ini juga dapat dimanfaatkan sebagai wahana edukasi bagi para pelajar untuk mengetahui makna dibalik bangunan ini secara historis. Tak heran banyak ilmuwan dan sejarawan yang datang hanya untuk sekedar meneliti dan mencari data/informasi mengenai Candi Jolotundo, selain itu juga para pelajar sering melakukan kunjungan untuk pengamatan di situs ini mulai dari jenjang TK hingga perguruan tinggi yang pastinya kegiatan tersebut dilakukan sebagai cara pengenalan dan pembelajaran kepada peserta didik agar dpaat mengetahui secara langsung peninggalan berserjarah ini.

Kesadaran sejarah menurut Jan Bakker adalah keinsyafan bahwa sesorang menerima dari nenek moyangnya hasil kerja mereka sebagai warisan yang paling dipelihara dan disempurnakan agar pada gilirannya hasil karya itu diteruskan kepada angkatan berikutnya.Dari pernyataan tersebut jelas bahwa kesadaran sejarah ini harus ada dan ditanamkan kepada setiap orang sehingga kesadaran sejarah harus ditanamkan sejak dini. Kesadaran sejarah harus ditanamkan agar dapat memilihara serta melestarikan warisan bangsa yang sudah ada secara turun temurun(Warto, 2017).

Kesadaran sejarah tidak lain merupakan sebuah kesadaran sebagai mahluk individu dan mahluk social untuk menjaga warisan budaya untuk kelestariannya agar generasi selanjutnya dapat menikmati eindahan dan nilai yang terkandung dalam warisan sejarah yang ada. Kesadaran sejarah tadalah kesadaran penuh yakan historis dalam setiaphal yang ada sekarang dan relavitas dari semua opini. Kesadaran sejarah dapat dicapai melalui pemahaman kesejarahan sesuai dengan tingkat perkembangan dan keterampilan berpikir kesejarahan sebagai kemampuan menganalisi dan mengapresiasi terhadap aktivitas manusia dimasa lampau dan hbungannya dengan sesame.

Kesadaran sejarah berarti menyadari dengan adanya kenyataan manusia hidup dari waktu ke waku pasi akan mengalami sebuah perubahan dan berkembang seiring dengan perkembangan zaman secara continue. Peserta didik dalam 
pembelajaran sejarah juga harus dituntut untuk kesadaran sejaranya sebagai generasi penerus bangsa.Pembelajaran sejarah dalam hubungannya dengan kesadaran sejarah sangat erat, yakni mencakup aspek kognitf, aspek afektif dan aspek psikomotor. Menurut Moedjanto (1989:14) yaitu keberanian berpijak pada fakta dan realitas, keinsyafan adanya continuity (kelangsungan atau kesinmabungan) dan keinsyafan akan kehauasan gerak maju yang terus menerus.

Berdasarkan hasil wawancara yang dilakukan oleh peneliti didapatkan fakta mengenai permasalahan lain yaitu guru merasa kesulitan dalam menyampaikan materi sejarah khususnya Hindu-Buddha karena materi yang cakupannya luas serta nama-nama tokoh yang panjang dan juga waktu serta tempat yang menjadi cakupan materi Hindu-Buddha sangat panjang. Berdasarkan hasil wawancara dengan peserta didik didapatkan bahwa kurangnya kesadaran peserta didik akan pentingnya menjaga peninggalan situs bersejarah, peserta didik jarang mengetahui peninggalan sejarah yang ada dilingkungan sekitarnya.

Penelitian yang dilakukan oleh Indah Ayu Ainina pada 2014 dalam Journal of Education Social Studies mengenai "Pemanfaatan Media Audio Visual Sebagai Sumber Pembelajaran Sejarah" dapat disimpulkan bahwa pemanfaatan media audiovisual yang dilakukan di SMAN 2 Bae Kudus ini berhasil, pemanfaatan video sebagai media pembelajaran sangat membantu peserta didik dalam pembelajaran sejarah sehingga nilai post test peserta didik tuntas $<70$. Penggunaan video sebagai media pembelajaran di nilai sangat efektif digunakan pada pembelajaran sejarah sehingga dapat meningkatkan hasil belajar peserta didik(Ainina, 2014).

Penelitian yang dilakukan oleh Riris Yuniarsih pada 2017 yang dimuat dalam Jurnal Bisnis dan Teknologi Politeknik NSC Surabaya mengenai "Pengembangan Objek Wisata Petirtaan Jolotundo Trawas, Mojokerto" dapat disimpulkan bahwa Petirtaan jolotundo ini merupakan objek wisata sejarah yang mempunyai potnsi yang cukup besar untuk dikembangkan agar tetap terjaga kelestariannya, karena wisata ini belum begitu terkenal maka harus dilakukan pengelolan yang lebih serius oleh instansi yangterkait agar wisata ini dapat terkenal hingga ke internasional. Potensi yang dimiliki oleh petirtaan candi ini sangat 
banyak dapat digunakan sebagai wisata religi, wisata budaya, wisata cagar alam dan wisata edukasi

Penelitian yang dilakukan oleh Tri Budiarto pada 2013 mengenai "Hubungan Antara Konsep Diri Dan Kesadaran Sejarah Dengan Prestasi Belajar Sejarah Nasional Indonesia Siswa SMU Negeri Di Kabupaten Sukoharjo" memberikan kesimpulan bahwa terdapat hubungan yang positif antara konsep diri dan kesadaran sejarah sehingga mendorong peserta didik untuk mencapai prestasi maksimal dalam pembelajaran sejarah nasional Indonesia.

\section{METODE}

Penelitian ini dilakukan di SMAN I Pacet, Mojokerto yang beralamatkan di Jl. Raya Pacet-Gondang, Mojokerto, Jawa Timur. Peneliti tertarik untuk melakukan penelitian di sekolah tersebut karena kurangnya pemanfaatan media pembelajaran audiovisual serta pengenalan situs-situs bersejarah yang ada disekitar yang kurang di ekspose keberadaanya, sehingga peneliti membuat film pendek mengenai situs Jolotundo.

Penelitian menggunakan metode pendekatan kuantitatif, dimana penelitian kuantitaf yang lebih menekankan analisisnya pada data angka-angka atau numeric dan data yang diperoleh dapat diolah dengan statistika. Penelitian ini menggunakan penelitian berjenis eksperimen dengan tujuan untuk menguji pengaruh media film pendek Candi Jolotundo sebagai variabel $\mathrm{X}$ dan Kesadaran sejarah sebagai variabel terikat (Y). Penelitian eksperimen meupakan penelitian yang menuntut peneliti untuk dapat mengendalikan satu atau lebih variable bebas maupun terikat untuk melihat perbedaanya atau dengan kata lain untuk melihat hubungan sebab-akibat pada dua atau lebih variabel.

\section{HASIL DAN PEMBAHASAN}

Petirtaan Jolotundo merupakan salah satu peninggalan bersejarah yang tepatnya berada di Desa Seloliman, Kecamatan Trawas, Kabupaten Mojokerto, Jawa Timur. Candi ini berada di kawasan pegunangan dan uniknya situs ini diapit oleh dua gunung yaitu Gunung Penanggungan dan Welirang(Sulistyo, Widodo, \& 
A, 2010). Candi ini secara geografis terletak di lereng gunung penanggungan yang letaknya memotong atau melintang sebagian lereng barat gunung.Candi ini sering disebut petirtaan karena memang situs ini memiliki mata air disetiap sudutnya.Candi ini berbentuk persegi yang berukuran 16x13 meter pesegi.Disudut timur dan tenggaranya terdapat kolam kecil yang diatasnya terdapat bangunan candi yang semakin ke atas semakin meruncing.Petirtaan ini dianggap suci bagi penganut Hindu-Siwa.

Candi Jolotundo adalah salah satu bukti kejayaan kerajaan Hindu-Buddha yang ada di Indonesia, peradaban yang maju pada masa lampau menjadikan Indonesia memiliki keberanekaragaman peninggalan sejarah seperti candi ini. Candi Jolotundo merupakan candi dibangun pada masa Raja Udayana sebagai bukti cinta kepada sang Istri. Candi ini merupakan salah satu candi yang unik yang berada di Kawasan Cagar Budaya Mojokerto, hal ini dikarenakan candi ini memiliki mata air sehingga disebut sebagai petirtaan. Meskipun masyarakat awam belum sepenuhnya mengenal dan mengetahui candi ini, akan tetapi candi ini memiliki hal yang unik dan juga warisan budaya bangsa Indonesia yang harus dilestarikan keberadaannya.

Observasi yang dilakukan oleh peneliti menekankan pada 7 aspek/item yang akan digunakan sebagai acuan pengambilan data untuk mendukung data penelitian.

Tabel 1. Hasil Observasi

\begin{tabular}{|l|c|}
\hline \multicolumn{1}{|c|}{ ASPEK } & KESESUAIAN \\
\hline Tujuan Pembelajaran & Sesuai \\
\hline Pengembangan Materi & Belum Sesuai \\
\hline Metode Pembelajaran & Belum Sesuai \\
\hline Media Pembelajaran & Belum Sesuai \\
\hline Evaluasi Pembelajaran & Sesuai \\
\hline Sumber Belajar & Belum Sesuai \\
\hline Sarana dan Prasana & Sesuai \\
\hline
\end{tabular}

Berdasarkan hasil observasi yang dilakukan di SMAN 1 Pacet, Mojokerto didapatkan hasil yakni: 


\section{Tujuan Pembelajaran}

Berdasarkan pengamatan yang dilakukan pada aspek tujuan pembelajaran yang digunakan dalam pembelajaran sejarah pada kelas 10 mengenai materi "Peninggalan Kerajaan Hindu-Buddha" sudah sesuai dengan kompetensi inti dan kompetensi dasar yang dipergunakan dalam kurikulum 2013. Kompetensi dasar yang digunakan berbunyi "3.6 Menganalisis karakteristik kehidupan masyarakat, pemerintahan dan kebudayaan pada masa kerajaan-kerajaan Hindu-Buddha di Indonesia dan menunjukan contoh bukti-bukti yang masih berlaku pada kehidupan masyarakat Indonesia masa kini”.

\section{Pengembangan Materi Pembelajaran}

Berdasarkan hasil observasi yang telah dilakukan oleh peneliti, pengembangan materi pembelajaran mengenai peninggalan Hindu-Buddha hanya didasarkan pada buku paket yang mana dengan buku tersebut digunakan sebagai acuan dalam materi pembelajaran. Jadi pengembangan materi mengenai peningglana Hindu-Buddha kurang. Jadi dalam kegiatan obsevasi yang dilakukan oleh peneliti dapat diketahui bahwa pengembangan materi yang dipergunakan dalam kegiatan pembelajaran sejarah dikelas 10 teruatama dalam materi HinduBuddha dinilai kurang, karena guru hanya berpatokan pada buku paket saja, sehingga materi yang disampaikan terbatas pada materi. Padahal pada kenyataannya buku paket yang telah disediakan tidak memuat informasi yang cukup luas, hanya menuliskan sebagian atau gambaran umum dari kerajaankerajaan Hindu-Buddha itu sendiri. Pada kaitanya dengan kerajaan Hindu-Buddha, di Mojokerto banyak sekali tinggalan-tinggalan dari kerajaan Hindu-Buddha yang belum tersentuh dan belum termuat dalam buku paket tersebut. Dengan mengaitkan pembelajaran sejarah dengan peninggalan-peninggalan sejarah yang ada di daerah sekitar, seharusnya sangat membantu peserta didik untuk lebih mengenal peninggalan sejarah yang ada disekitarnya dan bagi guru dapat mengembangkan materi pembelajaran sejarah dengan materi sejarah local tersebut. 
Dapat disimpulkan bahwa pengembangan materi yang dipergunakan oleh pendidik kaitanya dengan materi Kerajaan Hindu-Buddha pada kelas X ini dirasa kurang karena hanya berpatokan pada buku paket saja.

\section{Metode Pembelajaran}

Berdasarkan hasil observasi yang telah dilakukan pada aspek metode yang digunakan dalam pembelajaran secara lebih terpaut pada Problem Based Learning saja, penggunaan metode pembelajaran pada kurikulum 2013 ada 4 yaitu inquiry, problem based learning, project based learning dan discovery seharusnya pada guru dapat menggunakan keempatny sebagai variasi dalam pembelajaran sesuai dengan karakteristik peserta didik. Jadi penerapan metode pembelajaran sesuai dengan kurikulum 2013 ini belum semuanya diterapkan oleh pendidik Sdalam kegiatan belajar mengajar. Dalam penggunaan metode pembelajaran hanya terfokus pada PBL dan PjBL saja, dalam pembelajaran biasanya juga hanya berpatok pada PjBL seperti memberi topik permasalahan yang akan dibahas kemudian membuat sebuah produk dan di presentasikan. Setelah itu guru menggunakan metode ceramah dalam pembelajaran, jadi dapat disimpulkan bahwa di SMAN 1 Pacet belum sepenuhnya menerapkan metode yang ada dan tercantum dalam Kurikulum 2013, sehingga metode pembelajaran yang digunakan belum sesuai dengan apa yang tercantum dalam kurikulum 2013.

\section{Media Pembelajaran}

Berdasarkan kegiatan obsevasi yang dilakukan di SMAN 1 Pacet engenai aspek media pembelajaran didapatkan hasil yaitu "media pembelajaran yang digunakan dalam pembelajaran sejarah di SMAN 1 Pacet ini hanya menggunkan slide powerpoint dan buku acuan sejarah Indonesia. Belum ada media pembelajaran lain yang igunakan dalam pembelajaran sejarah.” Jadi dalam media pembelajaran yang digunakan terdapat 2 media yaitu media buku paket dan slide powerpoint. Penggunaan media pembelajaran yang dinilai belum bervariasi, karena pada kenyataannya media pembelajaran memang sangat dibutuhkan oleh peserta didik untuk menangkan informasi lebih mudah dengan bantuan alat media, buku dan 
slide powerpoint sebenanya belum cukup untuk memenuhi tuntutan dalam pembelajaran sejarah. Pendidik bias menggunakan media pembelajaran lain yang bias menjadi salah satu alternative digunakan agar peserta didik dapat menangkap informasi lebih optimal lagi dalam suatu pembelajaran. Pendidik dapat menggunakan media pembelajaran yang lain bukan hanya berpatok pada buku paket dan juga slide powerpoint yang digunakan, adakalanya pasti peserta didik membutuhkan alat bantu yang lain ketika pembelejaran berlangsung. Media pembelajaran bukan hanya didasarkan pada media visual saja akan tetapi media audiovisual juga dapat dipergunakan. Media audiovisual dapat menampilkan kombinasi gambar dan suara sehingga jika dipergunakan dalam pembelajaran sejarah akan lebih efektif dan juga memperjelas informasi yang akan di sampaikan ke peserta didik.

Jadi berdasarkan hasil observasi pada aspek media pembelajaran yang dipergunakan oleh pendidik dalam pembelajaran dikelas $\mathrm{X}$ dirasa kurang untuk memenuhi kebutuhan peserta didik dan belum relevan dalam menyampaika informasi kepada peserta didik.

\section{Evaluasi Pembelajaran}

Berdasarkan hasil observasi yang dilakukan di SMAN 1 Pacet pada aspek evaluasi pembelajaran didapatkan hasil bahwa "Evaluasi pembelajaran dilakukan dengan cara post-test, pre-test, ulangan harian, uts dan uas". Setelah dilakukan kegiatan observasi oleh peneliti didapatkan data bahwa dalam kegiatan evaluasi yang dipergunakan oleh guru yaitu post-test, pre-test, ulangan harian, uts dan juga uas. Secara keseluruhan penggunaan evaluasi pembelajaran ini sudah cukup kompleks untuk dapat mengukur kemampuan peserta didik baik sebelum maupun sesudah pembelajaran dilaksanakan. Jadi dapat disimpulkan bahwa penggunaan variasi dalam evaluasi pembelajaran yang dilakukan oleh pendidik dalam pembelajaran sejarah kelas X sudah sesuai.

\section{Sumber Belajar}


Berdasarkan hasil observasi yang dilakukan oleh peneliti mengenai aspek sumber belajar yang dipergunakan dalam pembelajaran sejarah khususnya pada kelas X didapatkan hasil bahwa "Sumber belajar yang digunakan hanya berpatok pada buku siswa sejarah indonesia serta lks". Jadi dalam pembelajaran sejarah peserta didik menggunakan buku paket dan lks sebagai sumber belajar, tidak ada referensi lain yang dipergunakan oleh peserta didik, sehingga dalam penggunaan sumber belajar masih harus ditambah lagi agar wawasan yang mereka peroleh juga luas didukung dengan sumber-sumber yang relevan dan memadai seperti bukubuku ataupun jurnal.

\section{Sarana dan Prasarana Pendukung Pembelajaran}

Berdasarkan hasil observasi yang telah dilakukan ooleh peneliti didapatkan data bahwa "Fasilitas yang digunakan untuk menunjang pembelajaran sudah ada LCD, speaker, perpustakaan dan koneksi wifi yang dapat menjangkau internet”. Jadi dalam penyediaan sarana dan prasarana yang terdapat di SMAN 1 Pacet ini sudah baik dan sangat mendukung dalam pembelajaran segala fasilitas dapat dipergunakan oleh peserta didik dan sarana prasarana yang adapu masih terawatt dan terjaga dengan baik. Sarana dan prasarana pendukung pembelajaran sejarah yang baik dalam kelas maupun luar kelas dirasa sudah tergolong dalam kriteria baik, sehingga peserta didik dapat memanfaatkan sarana dan prasana yang ada untuk menunjuang pembelajaran sejarah seperti LCD menayangkn slide powerpont ataupun video, speaker yang ada dimasing-masing kelas yang dapat dipergunakan oleh pendidik untuk menanyangkan video atau mendengarkan suara/rekaman suara(audio), perpustkaan yang didalamnya terdapat buku-buku referensi meskipun belum sepenuhnya lengkap, koneksi wifi yang sangat bermanfaat untuk mengkoneksikan dalam ke internet sehingga peserta didik dapat mengakses internet lebih mudah untuk mencari informasi-informasi atau sumber yang dapat dipergunakan untuk tugas yang diberikan oleh pendidik.

Jadi dapat disimpulkan bahwa dalam aspek sarana dan prasarana pendukung pembelajaran sudah baik dan dapat dikategorikan baik untuk mendukung proses belajar-mengajar dalam mata pelajara sejarah. 
Pengumpulan data yang kedua dilakukan dengan teknik wawancara. Berdasarkan hasil wawancara yang dilakukan oleh peneliti pada tanggal 18 April 2019 bertempat di SMAN 1 Pacet, Mojokerto. Narasumber yang akan menjadi informan pada penelitian ini yaitu Ibu Ony Iflakhah selaku guru pengampu mata pelarajan sejarah dikelas X. Dibawah ini merupakan penjelasan mengenai hasil wawancara dengan narasumber sebagai berikut:

\section{Kendala Dalam Pembelajaran Sejarah}

Berdasarkan wawancara yang telah dilakukan oleh peneliti kepada Ibu Ony selaku guru sejarah kelas X, maka di dapatkan data yaitu "1. Media pembelajaran, yang berakibat pada kurangnya ketertarikan peserta didik dalam mengikuti pembelajaran sejarah, 2. Nama tokoh yang Panjang, adanya nama alias sehingga sulit untuk dihafal oleh peserta didik, 3. Keturunan atau silsilah, karena dari satu kerajaan yang saling berhubungan". Jadi berdasarkan penuturan dari informan didapatkan fakta bahwa yang menjadi kesulitan terbesar adalah media pembelajaran karena dengan penggunaan media pembelajaran ini sangat berpengaruh terhadap minat dan daya Tarik peserta didik dalam mengikuti pembelajaran sejarah. Masalah lain yang dirasakan oleh pendidik yakni mengenai nama tokoh yang Panjang, serta memiliki nama alias sehingga hal ini menjadi kendala tersendiri bagi pendidik maupun peserta didik.

\section{Pengetahuan Mengenai Candi Jolotundo}

Berdasarkan wawancara yang telah dilakukan oleh peneliti kepada Ibu Ony selaku guru sejarah kelas X, maka di dapatkan data yaitu "Tahu, candi jolotundo merupakan salah satu peninggalan dari kerajaan beraliran Hindu-Siwa yang terletak di Trawas, Kabupaten Mojokerto". Kaitanya dengan pengetahuan pendidik mengenai situs ini menurut peneliti kurang, karena pada dasarnya guru belum mampu menjelaskan secara jelas mengenai informasi-informasi apa saja yang diketahui oleh guru tersebut mengenai Candi Jolotundo, padahal situs ini sendiri merupakan situs yang berada di sekitar lingkungan saja, meskipun jarak tempuh hamper $10 \mathrm{~km}$ akan tetapi Candi ini banyak dikunjungi baik oleh wisatawan 
maupun peneliti. Sehingga dirasa guru tersbeut belu sepenuhnya mengetahui tentang situs candi jolotundo ini.

\section{Candi Jolotundo Sebagai Media Pembelajaran}

Berdasarkan wawancara yang telah dilakukan oleh peneliti kepada Ibu Ony selaku guru sejarah kelas X, maka di dapatkan data yaitu "Bisa sekali". Menurut penuturan dari pengmapu mata pelajaran sejarah, candi jolotundo dapat digunakan sebagai media pembelajaran yang dipergunakan pada materi hindu-buddha.

\section{Pengenalan Peninggalan Sejarah Di Lingkungan Sekitar}

Berdasarkan wawancara yang telah dilakukan oleh peneliti kepada Ibu Ony selaku guru sejarah kelas X, maka di dapatkan data yaitu "Pernah, contohnya yaitu makam krapayak dan juga peninggalan-peninggalan sejarah yang ada di Trowulan seperti Candi Tikus, Wringin Lawang, Bajang Ratu dll”. Maka dapat disimpulkan bahwa pendidik belum memperkenalkan situs-situs bersejarah yang sangat beragam yang ada dilingkungan sekitar, hanya sebagian kecil saja yang diperkenalkan. Sebenarnya jika pendidik ingin memperkenalkan peninggalan bersejarah yang ada dilingkungan sekitar sangat banyak seperti Candi, arca, situs kuno, sarkofagus yang memang eksistensi dari benda-benda ini belum seterkenal situs yang ada di Kompleks Trowulan.

\section{Kelayakan Candi Jolotundo Sebagai Media Pembelajaran}

Berdasarkan wawancara yang telah dilakukan oleh peneliti kepada Ibu Ony selaku guru sejarah kelas $\mathrm{X}$, maka di dapatkan data yaitu "Layak, karena merupakan salah satu Candi Hindu yang masuk dimateri sejarah Hindu-Buddha dan juga merupakan salah satu warisam dari Airlangga". Maka dapat disimpulkan bahwa Candi Jolotundo ini layak digunakan sebagai media pembelajaran, berdasarkan pada unsur historis yang ada candi ini merupakan salah satu bukti adanya peradaban pada jaman kerajaan Hindu, candi ini memiliki nilai historis yang tinggi, dan juga candi ini merupakan salah satu peningalan dari Raja Airlangga. 


\section{Mengenal Warisan Bangsa Melalui Pembelajaran Sejarah}

Berdasarkan wawancara yang telah dilakukan oleh peneliti kepada Ibu Ony selaku guru sejarah kelas X, maka di dapatkan data yaitu "Cukup menenal, contohnya contohnya mengenal candi Borobudur dan Candi Prambanan sebagai candi-candi besar yang dimilki oleh Indonesia, serta candi-candi yang berada di kompleks Trowulan”. Dari paparan jawaban yang telah disampaikan oleh informan maka dapat disimpulkan bahwa melalui pembelajaran sejarah peserta didik dapat mengetahui beberapa warisan bangsa Indonesia seperti Candi-candi besar yang terdapat di Indonesia dan pastinya peserta didik pun tidak asing mendengar nama atau gambar dari peninggalan sejarah tersebut seperti Candi Borobudur dan Prambanan. Maka dari itu dengan adanya pembelajaran sejarah juga diharapkan peserta didik dapat mengenal dan mengetahui situs sejarah yang ada disekitarnya.

\section{Pengaruh Pembelajaran Sejarah Terhadap Terjaganya Warisan Bangsa}

Berdasarkan wawancara yang telah dilakukan oleh peneliti kepada Ibu Ony selaku guru sejarah kelas X, maka di dapatkan data yaitu "Iya, karena semakin mereka tahu tujuan pembuatan suatu candimaka mereka semakin mengehargai dan menjaga situs tersebut". Maka dapat disimpulkan bahwa pembelajaran sejarah dapat mempengaruhi pola piker peserta didik untuk tetap menjaga warisan budaya.

\section{Peran Pembelajaran Sejarah Terhadap Kelestarian Peninggalan Bersejarah}

Berdasarkan wawancara yang telah dilakukan oleh peneliti kepada Ibu Ony selaku guru sejarah kelas X, maka di dapatkan data yaitu "Melestarikan, mengetahui fungsi dan tujuan dibangunnya suatu bangunan dan mengetahui siapa pembuatnya". Jadi pembelajaran sejarah sangat berpotensial dalam memerankan perannya untuk pengenalan peninggalan sejarah serta memberikan wawasan terhadap peserta didikny untuk tetap menjaga kelestariannya.

Pengambilan data menggunakan angket/kuesioner dilakukan oleh peneliti pada tanggal 18 April 2019 bertempat di SMAN 1 Pacet, Mojokerto. Peneliti menggunakan 33 responden sebagai sampel dari keseluruhan populasi yang ada. 
Pengambilan data ini dilaksanakan dikelas $\mathrm{X}$ baik MIA maupun IIS menggunakan teknik random sampling atau acak. Maka didapatkan hasil bahwa:

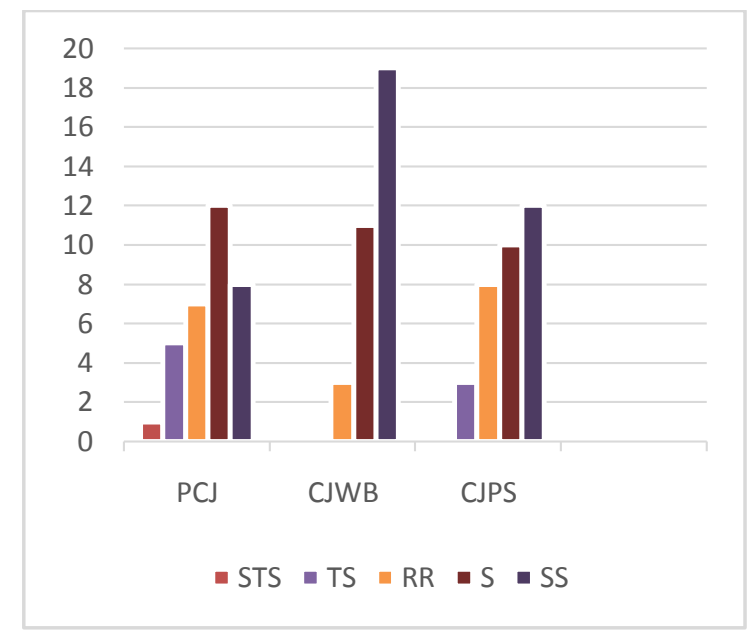

Gambar 1. Hasil Kuesioner

Dapat disimpulkan dari keseluruhan data yang ada dan telah dikumpulkan oleh peneliti bahwa pemahaman peserta didik mengenai Candi Jolotundo tergolong rendah, hal ini dikarenakan tingkat kesadaran peserta didik yang rendah pula. Kesadaran sejarah yang dimiliki oleh peserta didik belum sepenuhnya tumbuh disetiap individu, maka dalam hal ini diperlukan penelitian lanjut oleh peneliti untuk meningkatkan kesadaran sejarah yang di miliki oleh peserta didik. Berdasarkan penjelasan guru setelah diwawancara juga menjadi dasar bahwa kurangnya pengenalan pada benda-benda peninggalan sejarah yang ada dilingkungan sekitar. Pada kenyataan ini wilayah Mojokerto sangat potensial jika dimanfaatkan oleh pendidik untuk menumbuhkan dan meningkatkan kesadaran sejarah peserta didiknya.

Berdasarkan data kuesioner yang ada dapat diketahui bahwa sebagian besar peserta didik belum mengetahui bahwa Candi Jolotundo merupakan salah satu peninggalan sejarah. Hal ini yang menjadi dasar permasalahan bahwa kesadaran akan pentingnya sejarah belum tertanam dalam peserta didik, seharusnya dengan adanya pembelajaran sejarah baik pendidik maupun peserta didik dapat mengkaitkan pembelajaran yang ada dengan fakta yang ada dalam kehidupan sehari-hari. Candi Jolotundo memiliki nilai historis yang tinggi, akan tetapi 
keberadaannya belum sepenuhnya di ekspos seperti peninggalan-peninggalan sejarah yang ada dikompleks Trowulan. Kaitanya dengan perspetif peserta didik terhadap Candi Jolotundo pada kenyataanya banyak yang belum memahami letak candi, bentuknya seperti apa, bahkan ada yang tidak tahu bahwa Candi Jolotundo ini merupakan salah satu peninggalan sejarah. Jadi dengan penelitian ini dapat diketahui bahwa tingkat kesadaran peserta didik rendah.

\section{SIMPULAN}

Simpulan yang didapatkan pada penelitian ini yaitu berdasarkan data kuesioner yang ada dapat diketahui bahwa sebagian besar peserta didik belum mengetahui bahwa Candi Jolotundo merupakan salah satu peninggalan sejarah. Hal ini yang menjadi dasar permasalahan bahwa kesadaran akan pentingnya sejarah belum tertanam dalam peserta didik, seharusnya dengan adanya pembelajaran sejarah baik pendidik maupun peserta didik dapat mengkaitkan pembelajaran yang ada dengan fakta yang ada dalam kehidupan sehari-hari. Jadi dapat disimpulkan dari keseluruhan data yang ada dan telah dikumpulkan oleh peneliti bahwa pemahaman peserta didik mengenai Candi Jolotundo tergolong rendah, hal ini dikarenakan tingkat kesadaran peserta didik yang rendah pula. Kesadaran sejarah yang dimiliki oleh peserta didik belum sepenuhnya tumbuh disetiap individu, maka dalam hal ini diperlukan penelitian lanjut oleh peneliti untuk meningkatkan kesadaran sejarah yang di miliki oleh peserta didik.

\section{DAFTAR PUSTAKA}

Ainina, I. A. 2014. "Pemanfaatan Media Audio Visual Sebagai Sumber Pembelajaran Sejarah". Indonesia Journal of History Education, 3(1), 4045 .

Azhar, Arsyad. 2010. Media Pembelajaran. Jakarta: Raja Grafindo Persada.

Bappeda. 2014. "Potensi Kabupaten dan Kota Mojokerto". [Online] Terdapat pada: http://bappeda.jatimprov.go.id/bappeda/wpcontent/uploads/potensi-kabkota-2013/kabmojokerto-2013.pdf [Diakses 23 April 2019].

Collingwood, RG., The Idea of History. London: Oxford University Press. 
Gerlach dan Ely. 1971.Teaching \& Media: A Systematic Approach. Second Edition, by V.S. Gerlach \& D.P. Ely, 1980, Boston, MA: Allyn and Bacon. Copyright 1980 by Pearson Education

Hutapea, F., \& Purba, A. 2014. Pengaruh Penggunaan Media Pembelajaran Berbasis Video Terhadap Hasil Belajar Mengait Pada Siswa Tata Busana Smk Negeri 8 Medan. 58-66.

Kristinah, E \& Aris, S. 2007. Mutiara-Mutiara Majapahit. Mojokerto: Departemen Kebudayaan dan Pariwisata

Munandar, A. A. 2016. Arkeologi Pawitra. Jakarta: Wedatama Widya Sastra.

Rahadi, D. G. B. 2013. "Konsistensi Raja Airlangga Dalam Menjalankan Dharma Di Jawa Timur Abad X-XI M". Jurnal Pendidikan Sejarah. Vol. 1 (1):3242.

Sayono, J. (2013). "Pembelajaran Sejarah Di Sekolah: Dari Pragmatis Ke Idealis. Jurnal Sejarah Dan Budaya", 7(1), 109-123. Retrieved from http://journal.um.ac.id/index.php/sejarah-dan budaya/article/view/4733.

Sidomulyo, H. 2013. Mengenal Petirtaan Purbakala Di Gunung Penanggungan. Surabaya: UBAYA Press

Sulistyo, D. B., Widodo, J. P., \& A, A. F. A. 2010. Sejarah Wisata Jolotundo Trawas, Mojokerto Pada 1986-2010. (11).

Rahadi, D. G. B. 2013. "Konsistensi Raja Airlangga Dalam Menjalankan Dharma Di Jawa Timur Abad X-XI M". Jurnal Pendidikan Sejarah. Vol. 1 (1):3242.

Warto. 2017. "Menumbuhkan Kesadaran Sejarah Generasi Muda". Pendidikan Sejarah, (September), Hlm. 2-3.

Wulandari, A. 2013. "Upaya Pelestarian dan Pemanfaatan Petirtaan Jalatunda". Jurnal Pendidikan Sejarah. Vol 1(2):178-186. 